\title{
DAYA HAMBAT PERASAN JERUK NIPIS (Citrus aurantifolia) TERHADAP PERTUMBUHAN BAKTERI Enterococcus faecalis
}

\author{
Stanny Linda Paath ${ }^{*}$ Mirza Aryanto ${ }^{*}$, Dwita Citra Kurnia Ananda Putri ${ }^{* *}$ \\ "Departemen Konservasi, Fakultas Kedokteran Gigi, Universitas Prof.Dr.Moestopo(B), Jakarta \\ ${ }^{* *}$ Fakultas Kedokteran Gigi, Universitas Prof.Dr.Moestopo(B), Jakarta \\ Korespondensi: Stanny Linda Paath, stanny.linda@gmail.com
}

\begin{abstract}
ABSTRAK
Latar belakang: perawatan saluran akar merupakan salah satu perawatan endodontik untuk mempertahankan gigi dengan bagian jaringan pulpa yang sudah terinfeksi bakteri. Irigasi saluran akar merupakan salah satu proses yang sangat penting untuk mengeliminasi bakteri dalam saluran akar. Pada saluran akar gigi dengan perawatan endodontik yang gagal, ditemukan bakteri Enterococcus faecalis, sehingga diperlukan alternatif bahan irigasi yang lebih efektif. Tujuan: menjelaskan daya hambat perasan jeruk nipis (Citrus aurantifolia) sebagai bahan alternatif larutan irigasi dalam menghambat pertumbuhan bakteri Enterococcus faecalis pada perawatan saluran akar. Metode: sampel yang diuji berjumlah 32 berupa biakan bakteri Enterococcus faecalis dalam media agar BHI pada cawan petri. Penelitian ini menggunakan metode difusi cakram kertas. Setiap 1 cawan petri dibagi menjadi empat bagian dan diletakkan cakram kertas yang masing-masing telah diberikan perasan jeruk nipis (Citrus aurantifolia) kosentrasi 100\% dan kontrol positif $(\mathrm{NaOCl} 2,5 \%)$. Bakteri ditanam dan diinkubasi, kemudian diencerkan dengan standar konsentrasi bakteri McFarland I (1.10 $6 \mathrm{cfu} / \mathrm{ml})$. Hasil penelitian: besar rerata daya hambat bakteri Enterococcus faecalis dalam perasan jeruk nipis (Citrus aurantifolia) sebesar 5,8 $\pm 1,8 \mathrm{~mm}$, sedangkan pada larutan $\mathrm{NaOCl} 2,5 \%$ sebesar 3,9 $\pm 1,1 \mathrm{~mm}$. Uji hipotesis memiliki nilai $\mathrm{p}=0,000(\mathrm{p}<0,05)$. Kesimpulan: perasan jeruk nipis (Citrus aurantifolia) memiliki daya hambat bakteri Enterococcus faecalis yang lebih efektif.
\end{abstract}

Kata kunci: perasan jeruk nipis, Citrus aurantifolia, Enterococcus faecalis, perawatan saluran akar

\section{ABSTRACT}

Background: root canal treatment is an endodontic treatment to maintain teeth with part of the pulp tissue that has been infected with bacteria. Root canal irrigation is a very important process for eliminating bacteria in the root canal. Enterococcus faecalis is a bacteria commonly found specifically in failed root canal treatment. An alternative irrigation is needed to overcome these bacteria. Purpose: to explain the inhibition of lime juice (Citrus aurantifolia) as an alternative ingredient of irrigation solution in inhibiting the growth of Enterococcus faecalis bacteria in root canal treatment. Methods: thirty two samples in the form of Enterococcus faecalis bacterial culture in the BHI media were tested. This research uses paper disc diffusion method. Every 1 petri dish was divided into 4 parts and put paper discs which each had been given lime juice (Citrus aurantifolia) concentrate 100\% and positive control ( $\mathrm{NaOCl} 2,5 \%$ ). The bacteria were planted and incubated, then diluted to the standard concentration of the McFarland I bacteria (1.10 6 $\mathrm{cfu} / \mathrm{ml}$ ). Results: the average inhibitory capacity of Enterococcus faecalis bacteria in lime juice (Citrus aurantifolia) was $5.8 \pm 1.8 \mathrm{~mm}$, whereas in $\mathrm{NaOCl} 2.5 \%$ solution was $3.9 \pm 1.1 \mathrm{~mm}$. Hypothesis testing has a value of $p=0,000$ ( $p$ $<0.05)$. Conclusion: lime juice (Citrus aurantifolia) has a more effective inhibition of Enterococcus faecalis bacteria.

Keywords: Lime juice, Citrus aurantifolia, Enterococcus faecalis, root canal treatment

\section{PENDAHULUAN}

$\mathrm{P}$ erawatan saluran akar merupakan salah satu perawatan endodontik pada bidang kedokteran gigi dengan mengangkat semua jaringan pulpa yang terinfeksi oleh bakteri serta membentuk saluran akar agar dapat diisi dengan baik untuk men- cegah bakteri masuk kembali ke dalam saluran akar. ${ }^{1}$ Perawatan endodontik terdiri dari tiga tahapan yaitu preparasi akses saluran akar, pembersihan dan pembentukan saluran akar (cleaning and shaping), dan pengisian saluran akar (obturasi) atau biasa disebut triad endodontik. ${ }^{2}$ Pembersihan saluran akar dilakukan 
dengan cara mendesinfeksi saluran akar menggunakan larutan irigasi. ${ }^{3}$ Bahan irigasi yang paling banyak digunakan adalah natrium hipoklorit $(\mathrm{NaOCl}) 2,5 \%$, merupakan konsentrasi yang paling cocok dan umum digunakan pada perawatan saluran akar karena sifat sitotoksitasnya cukup rendah namun tetap menunjukkan aksi bakterisid dan dapat mempertahankan aktivitas pelarutan jaringan dan antimikroba. ${ }^{4,5}$ Pada perawatan endodontik yang gagal ditemukan bakteri Enterococcus faecalis, bertanggung jawab terhadap 80- 90\% infeksi saluran akar dan ditemukan pada $18 \%$ kasus infeksi endodontik primer, dan $67 \%$ pada kasus infeksi gigi setelah perawatan saluran akar. Bakteri ini dikenal sebagai bakteri yang dominan dan paling sering ditemukan pada kasus kelainan setelah perawatan saluran akar. Hal ini disebabkan Enterococcus faecalis dapat beradaptasi pada kondisi yang kurang menguntungkan seperti hiperosmolariti, panas, asam, dan basa. Spesies ini juga dapat bertahan tanpa dukungan dari bakteri lain dan menghasilkan perubahan patologis melalui produksi racun atau secara tidak langsung melalui proses inflamasi. ${ }^{6,7,8,9}$ Jeruk nipis (Citrus aurantifolia) merupakan salah satu tanaman yang mempunyai aktivitas antimikroba dan dapat digunakan sebagai alternatif larutan irigasi berbahan alami. Pada tahun 2016, Talitha melakukan penelitian mengenai perasan jeruk nipis (Citrus aurantifolia) konsentrasi $100 \%$ memiliki efek daya hambat bakteri lebih baik dibandingkan dengan hidrogen peroksida $\mathrm{H}_{2} \mathrm{O}_{2}$ konsentrasi 3\% terhadap pertumbuhan bakteri Enterococcus faecalis dilihat dari zona hambat. ${ }^{10}$ Jeruk nipis (Citrus aurantifolia) memiliki berbagai kandungan senyawa kimia yang bermanfaat seperti: asam sitrat, asam amino (triptofan dan lisin), minyak atsiri (sitral, limonen, lemon kamfer, geranilasetat, linalilasetat, felandren, kadinen, aktildehid, nonildehid), glikosida, lemak, damar, asam sitrun, kalsium, fosfor, besi, belerang vitamin B1, vitamin C, saponin dan flavonoid. Kandungan senyawa flavonoid pada jeruk nipis (Citrus aurantifolia) merupakan golongan senyawa polifenol terbesar yang memiliki aktivitas sebagai antioksidan dan antibakteri. Flavonoid dapat berperan sebagai antibakteri dengan cara mendenaturasi protein dan merusak sel bakteri. ${ }^{11}$

\section{METODE PENELITIAN}

Jenis penelitian yang digunakan adalah penelitian eksperimental laboratorium karena penelitian melakukan di laboratorium. Desain penelitian yang digunakan adalah Post-Test Only Control Group Design. Sampel penelitian yang digunakan adalah biakan bakteri Enterococcus faecalis. Variabel yang digunakan adalah perasan jeruk nipis (Citrus aurantifolia) dengan konsentrasi 100\%. Perhitungan sampel dilakukan dengan menggunakan Rumus Federer. Berdasarkan hasil perhitungan maka ditentukan enam belas sampel pada setiap kelompok sehingga jumlah sampel seluruhnya adalah 32 sampel. Metode difusi cakram kertas digunakan untuk mengukur zona hambat yang terbentuk. Pada penelitian ini, data yang dianalisis menggunakan aplikasi komputer. Semua data yang terdistribusi normal diuji dengan uji t-independen (independent $t$ test) untuk melihat perbedaan dari daya hambat bakteri yang terbentuk dengan perasan jeruk nipis (Citrus aurantifolia) dengan konsentrasi 100\%, hasil tersebut dilanjutkan dengan uji Shapiro-Wilk. Namun, jika data yang dihasilkan tidak terdistribusi normal atau $\mathrm{p}<0,05$ maka dilakukan analisis menggunakan uji non parametrik. Data yang dihasilkan kemudian diuji kembali dengan uji Mann-Whitney test.

\section{HASIL PENELITIAN}

Hasil penelitian uji daya hambat perasan jeruk nipis (Citrus aurantifolia) konsentrasi 100\% terhadap bakteri Enterococcus faecalis menggunakan metode difusi cakram kertas. Daya hambat bakteri ditandai dengan tidak tumbuhnya bakteri Enterococcus faecalis di sekitar cakram kertas berupa zona hambat atau zona bening. Zona hambat akan diukur dengan menggunakan jangka sorong digital dalam satuan millimeter.

Berdasarkan tabel 1 di bawah ini dapat diketahui bahwa uji normalitas pada data daya hambat pertumbuhan bakteri Enterococcus faecalis setelah diberikan perasan jeruk nipis (Citrus aurantifolia) konsentrasi 100\% menghasilkan data statistik Shapiro Wilk sebesar 0.907 dengan $p$ value sebesar 0.009 . Hal ini dapat diketahui bahwa $p$ value $(0.009)<$ level of significance $(\alpha=0.05)$, maka pada taraf nyata $5 \%$ diambil kesimpulan bahwa kelompok data tersebut dinyatakan tidak berdistribusi normal.

Uji normalitas pada data daya hambat pertumbuhan bakteri Enterococcus faecalis setelah pemberian larutan natrium hipoklorit (NaOCL) konsentrasi 2,5\% menghasilkan statistik Shapiro Wilk sebesar 0.956 dengan $p$ value sebesar dan 0.219 . Hal ini dapat diketahui bahwa $p$ value $(0.219)>$ level of significance $(\alpha=0.05)$, maka pada taraf nyata 5\% dapat diambil kesimpulan bahwa kelompok data tersebut dinyatakan berdistribusi normal.

Tabel 1. Uji Normalitas

\begin{tabular}{ccc}
\hline Kelompok Data & Shapiro Wilk & p value \\
\hline Larutan Perasan Jeruk Nipis & 0.907 & 0.009 \\
\hline Larutan Natrium Hipoklorit & 0.956 & 0.219 \\
\hline
\end{tabular}

Berdasarkan hasil pengujian yang tertera pada tabel di atas dapat diketahui bahwa statistik z sebesar -4.565 dan $p$ value yang dihasilkan sebesar 0.000 . Karena $p$ value $(0.000)<$ level of significance $(\dot{\alpha}=$ 0.05) maka $\mathrm{H}_{0}$ ditolak, artinya dapat dinyatakan bahwa ada perbedaan signifikan daya hambat pertumbuhan 
bakteri Enterococcus faecalis setelah diberikan perasan jeruk nipis (Citrus aurantifolia) dan pemberian natrium hipoklorit ( $\mathrm{NaOCL}$ ).

Nilai rerata daya hambat pertumbuhan bakteri Enterococcus faecalis setelah diberikan perasan jeruk nipis yang dapat dilihat pada tabel 2 yaitu sebesar 5.7747 (standar deviasi 1.74721) dan nilai rerata daya hambat pertumbuhan bakteri Enterococcus faecalis setelah pemberian natrium hipoklorit ( $\mathrm{NaOCL}$ ) sebesar 3.9106 (standar deviasi 1.12384), Hal ini menunjukan bahwa secara statistik daya hambat pertumbuhan bakteri Enterococcus faecalis setelah pemberian perasan jeruk nipis (Citrus aurantifolia) cederung lebih tinggi daripada daya hambat pertumbuhan bakteri Enterococcus faecalis setelah pemberian natrium hipoklorit ( $\mathrm{NaOCL})$.

Tabel 2. Uji Mann Whitney

\begin{tabular}{lcccc}
\hline \multicolumn{1}{c}{ Kelompok } & Mean & $\begin{array}{c}\text { Std. } \\
\text { Deviasi }\end{array}$ & $\begin{array}{c}\text { Statistik } \\
\mathbf{z}\end{array}$ & $\begin{array}{c}\mathbf{p} \\
\text { value }\end{array}$ \\
\hline $\begin{array}{l}\text { Perasan } \\
\text { Jeruk Nipis }\end{array}$ & 5.7747 & 1.74721 & -4.565 & 0.000 \\
$\begin{array}{l}\text { Natrium } \\
\text { Hipoklorit }\end{array}$ & 3.9106 & 1.12384 & & \\
\hline
\end{tabular}

Berdasarkan hasil pengujian yang tertera pada tabel di atas dapat diketahui bahwa statistik z sebesar -4.565 dan $p$ value yang dihasilkan sebesar 0.000 . Karena $p$ value $(0.000)<$ level of significance $(\alpha=$ 0.05) maka $\mathrm{H}_{0}$ ditolak, artinya dapat dinyatakan bahwa ada perbedaan signifikan daya hambat pertumbuhan bakteri Enterococcus faecalis setelah diberikan perasan jeruk nipis (Citrus aurantifolia) dan pemberian natrium hipoklorit ( $\mathrm{NaOCL})$.

\section{PEMBAHASAN}

Hasil penelitian menunjukkan bahwa perasan jeruk nipis (Citrus aurantifolia) konsentrasi 100\% dan natrium hipoklorit $(\mathrm{NaOCl})$ konsentrasi 2,5\% mempunyai zona hambat di sekitar cakram kertas, yang menunjukkan bahwa kedua kelompok tersebut memiliki daya hambat terhadap pertumbuhan bakteri Enterococcus faecalis. Berdasarkan hasil uji perbedaan non parametric Mann-Whitney yang telah dilakukan, menunjukkan bahwa perasan jeruk nipis (Citrus aurantifolia) memiliki daya hambat yang lebih kuat tetapi tidak signifikan dibandingkan dengan daya hambat natrium hipoklorit $(\mathrm{NaOCl})$ konsentrasi 2.5\% terhadap pertumbuhan bakteri Enterococcus faecalis. Hal ini disebabkan oleh adanya senyawa bioaktif dalam perasan jeruk nipis (Citrus aurantifolia) yang mempunyai sifat antibakteri untuk menghambat pertumbuhan bakteri dengan mekanisme hambatnya masing-masing, antara lain dengan cara merusak dinding sel, merusak membran sitoplasma sel, me- ngubah struktur molekul protein dan asam nukleat, serta menghambat kerja enzim bakteri. Senyawa fenol dan flavonoid juga dapat bersifat sebagai antioksidan. ${ }^{12}$

Menurut David dan Stout pada tahun 1971, daya antibakteri dapat dibagi menjadi empat riteria dengan melihat zona hambat yang terbentuk pada sekitaran cakram kertas. Penilaian zona hambat dilihat dari hasil pengukuran diameter. Jika diameter zona hambat 5 mm atau kurang dikategorikan lemah, diameter zona hambat 5-10 mm dikategorikan sedang, diameter zona hambat 10-20 mm dikategorikan kuat, dan diameter zona hambat $20 \mathrm{~mm}$ atau lebih dikategorikan sangat kuat. ${ }^{10,13}$ Mengacu pada kriteria ini perasan jeruk nipis (Citrus aurantifolia) konsentrasi 100\% dan natrium hipoklorit (NaOCL) konsentrasi 2,5\% memiliki daya anti bakteri yang kuat.

Penelitian ini sesuai dengan penelitian yang telah dilakukan sebelumnya oleh Lauma dan Pangemanan pada tahun 2015 telah membuktikan perasan jeruk nipis (Citrus aurantifolia) konsentrasi 100\% memiliki efek daya hambat bakteri lebih baik dibandingkan dengan klindamisin terhadap pertumbuhan bakteri Staphylococcus aureus secara in vitro dilihat dari zona hambat, serta Talitha pada tahun 2016 menjelaskan bahwa perasan jeruk nipis (Citrus aurantifolia) konsentrasi $100 \%$ memiliki efek daya hambat bakteri lebih baik dibandingkan dengan hidrogen peroksida $\mathrm{H}_{2} \mathrm{O}_{2}$ konsentrasi 3\% terhadap pertumbuhan bakteri Enterococcus faecalis dilihat dari zona hambat. ${ }^{10,14}$

\section{KESIMPULAN DAN SARAN}

Hasil dari penelitian ini menyatakan bahwa terdapat daya hambat perasan jeruk nipis (Citrus aurantifolia) konsentrasi 100\% terhadap pertumbuhan bakteri Enterococcus faecalis. Penelitian ini masih dirasa kurang valid karena tidak dilakukan uji fitokimia untuk mengetahui lebih jelas komponen senyawa bioaktif yang terdapat dalam perasan jeruk nipis (Citrus aurantifolia).

\section{DAFTAR PUSTAKA}

1. Cohen S., Hargreaves, K.M. Pathways of the Pulp 9th ed. St. Louis: Mosby Elseviers. 2006: 262-281; 318-348.

2. Chandra BS, Gopikrishna V. Grossman's Endodontic Practice 13th ed. India: Walter Kluwers Health. 2016

3. Mutia R. Efek Antibakteri Minyak Atsiri Kayu Manis terhadap Enterococcus faecalis Sebagai Bahan Medikamen Saluran Akar secara In Vitro [tesis]. Medan: Universitas Sumatera UAntibacterial Effictara. 2010.

4. Zand V, Lotfi M, Soroush MH, Abdollahi AA. Antibacterial Efficacy of Different Concentrations of Sodium Hypochlorite Gel and Solution on Enterococcus faecalis Biofilm. Iran Endod J,2016; 11(4): 315-319

5. Ustun, Yakup, Burak Sagsen, Suleyman Durmaz, Duygu Percin. In Vitro Antimicrobial Efficiency of Different Root Canal Sealers Against Enterococcus faecalis. European Journal of General Dentistry. 2013; 2(2): 135. 
6. Wang Q, Zhang C, Chu C, Zhu X. Prevalence of Enterococcus faecalis in saliva and filled root canals of teeeth associated with apical periodontitis. Int J Oral Sci. 2012; 4(1): 19-23

7. Ariani G.A, Wignyo H. Perawatan Ulang Saluran Akar Incisivus Lateral Kiri Maksila dengan Medik Kalsium Hidroksida-Chlorhexidine. Majalah Kedokteran Gigi. 2013; 20(1): 52-57.

8. Fisher K, Phillips C. The Ecology, Epidemiology and Virulence of Enterococcus. Inggris: University of Northampton. 2009; 155(2): 1749-1757.

9. Wardhana, D.V., Rukmo, M., Budi, A.T. Daya Antibakteri Kombinasi Metronidazol, Siprofloksasin, dan Minosiklin terhadap Enterococcus faecalis. Jurnal Konservasi Gigi. 2008; 1(1): 23-28.

10. Talitha Maghfira, Yanuar Ichrom, Lia Yulia. Uji Efektifitas Antibakteri Air Perasan Jeruk Nipis (Citrus aurantifolia) Sebagai Bahan Irigasi Saluran Akar Alami terhadap Pertumbuhan Enterococcus faecalis In Vitro. Jurnal Kedokteran Gigi. 2016 (1): 124-128.
11. Adindaputri, Zenia., Nunuk Purwanti., Ivan Arie Wahyudi. Pengaruh Ekstrak Kulit Jeruk Nipis (Citrus aurantifolia Swingle) Konsentrasi 10\% terhadap Aktivitas Enzim Glukosiltransferase Streptococcus mutans. Majalah Kedokteran Gigi. 2013; 20(2): 126-131.

12. Lauma, S.W., Pangemanan, D.H.C., dan Hutagalung, B.S.P. Uji Efektifitas Perasan Air Jeruk Nipis (Citrus aurantifolia S) terhadap Pertumbuhan Bakteri Staphylococcus aureus secara In Vitro. Jurnal Ilmiah Farmasi.2015; 4 (4): 9-15.

13. Davis WW, Stout TR. Disc Plate Method of Microbiology Antibiotic Assay. Microbiology. 1971; 22(4): 659-65

14. Lauma, S.W., Pangemanan, D.H.C., dan Hutagalung, B.S.P. Uji Efektifitas Perasan Air Jeruk Nipis (Citrus aurantifolia S) terhadap Pertumbuhan Bakteri Staphylococcus aureus secara In Vitro. Jurnal Ilmiah Farmasi.2015; 4 (4): 9-15 